\title{
A dialética da comunicação síncrona no ciberespaço na produção de sentido
}

\section{The dialectic of synchronous communication in the cyberspace in meaning production}

\begin{abstract}
Resumo:
Este artigo tem por foco analisar a dialética da comunicação síncrona no ciberespaço considerando a linguagem como produto e produtora de sentido à luz de Bakhtin e Vygotsky. Para isso, são apresentados para discussão teórica elementos como gênero, discurso e linguagem que permitem contextualizar o espaço de pesquisa enquanto gênero digital e suas características nos gêneros emergentes. Uma análise sócio-histórica e dialógica do corpus de um chat educacional a respeito da linguagem construída pelos sujeitos participantes finalizam o presente artigo.

Palavras-chave: Linguagem. Chat. Interação social. Mediação.
\end{abstract}

\section{Abstract:}

This work aims to analyze the synchronous dialectic of communication in cyberspace considering the language as product and producer of meaning from Bakhtin's and Vygotsky's focus. For this, theoretical discussion are presented included elements like genre, speech and language which contextualizes the research space as digital and emerging genres in their characteristics. A socio-historical analysis and dialogue of the body of an educational chat about the language constructed by the subjects participating finalizing this work.

Keywords: Language. Chat. Social interaction. Mediation.

BEZ, Maria Rosangela; PASSERINO, Liliana Maria; ALVES, Evandro. A dialética da comunicação síncrona no ciberespaço na produção de sentido. Informática na Educação: teoria \& prática, Porto Alegre, v. 13, n. 1, p. 91-100, jan./jun. 2010.

\author{
Maria Rosangela Bez \\ Liliana Maria Passerino \\ Evandro Alves \\ Universidade Federal do Rio Grande do Sul
}

\section{Introdução}

$\mathbf{N}$ ovos espaços de mediação surgem com o advento da Internet a partir de novas tecnologias da informação e comunicação, que culminam na comunicação eletrônica (escrita via chats, fóruns). Estes espaços são, ao mesmo tempo, semióticos e sociais, na medida em que permitem a produção de sentidos e a subjetivação a partir da interação social. Estes espaços afetam a mediação pela linguagem oral/escrita, pois a ela incorpora novos signos semióticos e trocas entre os sujeitos, adaptando a linguagem a estes espaços. A comunicação eletrônica pode ser percebida principalmente entre os jovens nascidos no final do século $X X$, pois para estes a interação mediada pelo computador já se tornou corriqueira. Mas como a escrita eletrônica pode afetar a circulação na/mediação pela linguagem em um espaço acadêmico? Mais precisamente, em uma disciplina de Pós-Graduação que se vale dessas ferramentas de comunicação no entorno de um ambiente virtual de aprendizagem em seu componente a distância?

Este estudo colocará em enfoque a linguagem nesta circunstância específica. Tem as perspectivas de Bakhtin e de Vygotsky como 
arcabouços teóricos principais que permitem analisar as interações em espaços digitais. Como estudo de caso foi escolhido o corpus de um chat, demonstrando-se como através da linguagem digital as trocas intencionais e mediadas tem ocorrido e como este novo gênero de discursivo vem se constituindo e alterando as relações entre os sujeitos.

Para atingir este objetivo, o presente artigo se organiza da seguinte maneira: iniciase com uma discussão teórica sobre gêneros, discurso e linguagem a partir das concepções inter-relacionadas de Bakhtin e Vygotsky; posteriormente, se apresenta o estudo de caso para finalizar com a análise e resultados encontrados. Pesquisas futuras e possíveis desdobramentos são assinalados nas considerações finais.

\section{Gênero e linguagem}

Para que se possa realizar uma análise dos impactos da digitalização (linguagem empregada) nas interações humana a noção bakhtiniana de gêneros do discurso é indispensável.

Bakhtin (2003) define os gêneros discursivos a partir do uso concreto da linguagem nas diferentes esferas de atividade humana. Para o autor, tais gêneros estabilizam algumas formas enunciativas que passam a ser consideradas características de uma determinada comunidade, ao mesmo tempo em que orientam a produção de novos textos, que passam ser reconhecidos como a essa comunidade pertencentes. A noção de gêneros discursivos, atuando como mecanismo de regulação parcial das produções em linguagem, permite que se faça uma caracterização adequada das formas e usos da linguagem para cada texto produzido em determinado contexto social.

Para Marcuschi (2005), gênero é um elemento importante da cultura comunicativa de uma sociedade e as TICs têm propiciado o surgimento de uma grande variedade de novos gêneros (Blogs, Fóruns, Chat, entre outros). Graças à comunicação mediada por computador (CMC), novas formas de interação vêm sendo adotadas, estabelecendo diferenças outras entre linguagem falada e a escrita do que aquelas conhecidas até o momento. Destacase que os gêneros discursivos, em Bakhtin, assumem formas sociais de organização típicas da vida cultural e não meramente categorias taxonômicas. Isso porque, basicamente, todo gênero possui duas funções: a de ser, simultaneamente, um instrumento comunicativo e uma forma de ação social. Portanto, a análise de um gênero precisa realizar um movimento dialético que considere tanto as intenções comunicativas como as formas de ação e produção dos participantes.

Dentro dessa perspectiva de análise, a CMC pode ser entendida como engendradora de novas formas de mediação comunicativa, a produzir novas atividades humanas, formando novas comunidades discursivas; e, conseqüentemente, novas estruturas enunciativas que merecem ser consideradas e investigadas como fruto do desenvolvimento humano. As mídias, no caso, meio digital, alteram as formas de comunicação do homem no curso de sua história, transformando, incorporando e refletindo as necessidades sociais da época atual. Elas modificam as formas de produção e recepção de textos e os meios de organização de suas mensagens.

Em particular, a comunicação eletrônica via Internet pode ser vista como protótipo de novas formas de comportamento comunicativo. Conhecer essas formas a partir de suas características genérico-discursivas é uma das maneiras de recuperar a função social de todo signo: a de mediar as relações humanas em toda a sua complexidade.

Todo gênero discursivo é situado histórico, social e culturalmente, por serem produtos de relações complexas entre um meio, um uso e a linguagem. Dito de outra forma, um gênero é um artefato cultural que permite desenvolver ações (que envolvem o contexto social) em situações específicas (que envolvem o cultural e o histórico), que se definem por objetivos comunicativos, audiência, regularidades formais e conteúdos.

Desta forma, um gênero é um elemento dinâmico e dinamizador do ato comunicativo, pois estrutura a comunicação criando expectativas partilhadas acerca da forma e do conteúdo da interação (MARCUSCHI, 2005).

Um gênero como artefato cultural contém (ERICJSON, 2000):

- Propósito comunicativo;

- Natureza da comunidade discursiva;

- Regularidades de forma e conteúdo, expectativas subjacentes e convenções; 
Propriedades das situações em que o gênero é utilizado, incluindo forças institucionais, sociais e tecnológicas que dão origem às regularidades do discurso.

É importante destacar que as distinções entre um gênero e outro não são predominantemente lingüísticas, mas sim funcionais; é justamente esta diferenciação funcional que nos interessa focar no presente estudo.

\section{A linguagem analisada à luz de Bakhtin e Vygotsky}

O papel da linguagem na construção do indivíduo, segundo Bakhtin e Vygotsky, é fundamentado na palavra, já que é através dela que ocorre a interação social. A linguagem é o meio pelo qual o indivíduo percebe o sentido das coisas, assim como é através dela que o homem se constrói como sujeito. O individuo, através da linguagem, organiza sua vida mental e, neste processo, estabelece a constituição de sua consciência.

A condição de mediação da tomada de consciência e organização do pensamento através do ato comunicativo, pela troca com as palavras e idéias, aponta à importância das interações e ao papel do outro no processo de significação. Pois: "Se o mundo se nos apresenta simbolicamente não há possibilidade de conteúdos cognitivos integrais ou domínios do pensamento fora da linguagem, nem possibilidade integrais da linguagem fora dos processos interativos humanos" (MORATO, 1996, p. 18).

Bakhtin e Vygotsky procuram compreender a realidade humana através da análise da linguagem na relação do sujeito consigo mesmo, na relação com outros sujeitos, e com a sociedade. Através da linguagem, constroem-se o pensamento e os próprios sujeitos; é por meio dela que o ser humano constrói sua realidade, seu universo, situando-se e sendo situado sócio-historicamente.

Desta forma, a linguagem é construção do pensamento; e a linguagem, antes de ser veículo de sentimentos, idéias, emoções, aspirações, é um processo criador em que organizamos as nossas experiências (FRANCHI, 1977 apud MORATO, 1995). Porém, a linguagem não apenas organiza e estrutura experiências como também é organizada e estruturada por essas, uma vez que a "mesma linguagem que é mediação social é o meio principal de mediação da atividade cognitiva" (FRANCHI, 1977 apud MORATO, 1995, p. 92).

Para Bakhtin, a análise da linguagem enfatiza as conexões entre o que se enuncia (através da oralidade ou da escrita) e as condições de sua enunciação. Afirma, assim a natureza social da linguagem e seu potencial de mediação sígnica entre os sujeitos. Bakhtin (1997, p. 14) relata que "a fala está ligada às condições de comunicação, que, por sua vez, estão ligadas às estruturas sociais". Dessa forma, para se analisar um fenômeno da linguagem, este jamais pode ser separado de seu conteúdo ideológico ou vivencial, pois essa separação acarreta monólogos mortos e descontextualizados, isto é, ocasiona uma enunciação monológica..

Na teoria bakhtiniana, a palavra ocupa um lugar de destaque. Exercendo a função de signo, que segundo Bakhtin:

Os signos só podem aparecer em um terreno interindividual. Ainda assim, trata-se de um terreno que não pode ser chamado de 'natural' no sentido usual da palavra: não basta colocar face a face dois homo sapiens quaisquer para que os signos se constituam. É fundamental que esses dois indivíduos estejam socialmente organizados, que formem um grupo (uma unidade social): só assim um sistema de signos pode constituir-se. (BAKHTIN, 1997, p. 35)

Bakhtin aponta que a palavra, além de ser parcialmente determinada pelo contexto, valor ideológico, ela opera como símbolo mediador da constituição de espaços. No caso especifico deste estudo, que versa sobre ambiente virtual de aprendizagem e, mais precisamente, na utilização da ferramenta chat no Ensino Superior, a linguagem atua neste sentido ao constituir, neste contexto, um espaço compartilhado em que, através das trocas comunicacionais, estabelecem-se, ao mesmo tempo, condições de enunciação e potenciais de interação entre os integrantes da disciplina, alunos e professor.

Contudo, tais condições de enunciação e potenciais de interação não se estabelecem a priori. Para Bakhtin (2003), o jogo das significações, possui uma abertura às novas enunciações que, inclusive, podem afetar dinâmica deste jogo, posto que as enunciações não são apartadas do contexto; pelo contrário, as enunciações, ainda que de uma natureza distinta da do contexto físico, acabam atuando na configuração deste contexto. Por isso, a 
análise a se fazer do fenômeno da linguagem deixa de buscar um sentido único para o que é dito, e busca compreender a conexão entre as enunciações e os contextos nos quais elas podem ser proferidas. Em outras palavras, importa menos o significado das palavras, entendido como o sentido dicionarizado que o termo possui, e mais os sentidos que podem ser produzidos pelo emprego das palavras em determinado contexto.

Ainda segundo Bakhtin, há uma diferenciação entre o sentido das enunciações e o seu significado, descrevendo que cada enunciado caracteriza-se por seus significados e sentidos. O sentido constitui-se contextualmente, efetivando-se por uma compreensão ativa e complexa, onde o ouvinte se relaciona com o que esta sendo relatado, com o que ele está entendendo e assim prepara uma resposta ao enunciado. Já o significado de uma palavra é a abstração de um termo da comunicação verbal e para sua definição única e dicionarizada, que exige do ouvinte apenas uma compreensão passiva.

Embora não se trate de uma oposição entre significado e sentido, Bakhtin enfatiza que é primordialmente na comunicação verbal entre sujeitos que a linguagem está ligada à vida e somente nestas condições que a palavra prolifera sentidos. Os significados das palavras surgem a posteriori de seu emprego na comunicação verbal, como fruto de uma abstração. As falas da vida encontram-se intensamente ligadas às ações cotidianas. Esta conexão entre linguagem e vida constitui o contexto extra-verbal pelo qual a comunicação verbal passa a ser não somente um simples fenômeno lingüístico, mas um enunciado repleto de sentido para o ouvinte, um fenômeno de linguagem. É através da interação social, que os participantes do ambiente escolar efetivamente, por exemplo, situam-se e buscam serem situados contextualmente.

Segundo Kuschnir (2007), Bakhtin descreve que a língua não é um produto acabado, nem um objeto herdado que possa ser transmitido de geração em geração. Assim, não é pela imitação que a criança se apropria da língua materna, pois "os indivíduos não recebem a língua pronta para ser usada; eles penetram na corrente da comunicação verbal; ou melhor, somente quando mergulham nesta corrente é que sua consciência desperta e começa a operar" (BAKHTIN, 1997, p. 108).
Segundo Kuschnir:

Sob essa visão, Bakhtin pontua que a língua não é transmitida como um sistema finito e definitivo; ela dura e perdura sob a forma de um processo evolutivo contínuo. Dessa forma, Bakhtin vê a linguagem numa perspectiva de totalidade, integrada à vida humana, em que a comunicação humana (verbal) não pode ser compreendida fora de sua ligação com uma situação concreta [...] (KUSCHNIR, 2007, p. 79).

Para Bakhtin, a enunciação é vista como a unidade da comunicação verbal e esta é de natureza social. Para que se possa entendê-la é importante compreender que ela está sempre em interação. Pois é num contexto social que é produzido o enunciado, não necessariamente ante um interlocutor presencial, mas na pressuposição de sua existência. O leitor/ ouvinte é, então, caracterizado por Bakhtin como o outro, presença física ou presumida de uma audiência imaginária.

Na perspectiva de Vygotsky (1998), partese da visão do eu com o outro para se descrever a necessidade das mediações para o desenvolvimento do aprendizado; mediações que podem ser por instrumentos e signos, assim como, também pela própria linguagem. Para Oliveira (1993, p. 27), "Vygotsky trabaIha, então, com a noção de que a relação do homem com o mundo não é uma relação direta, mas, fundamentalmente, uma relação mediada", com especial destaque na linguagem.

Para Vygotsky, a linguagem tem uma dupla função, primeiro comunicativa, no sentido da enunciação e de generalização pois:

Para comunicar alguma vivência ou algum conteúdo da consciência a outra pessoa não há outro caminho a não ser a inserção desse conteúdo numa determinada classe, em um grupo de fenômenos, e isto, como sabemos, requer necessariamente generalização. (VYGOTSKY, 2001, p. 12).

O desenvolvimento da linguagem coloca-se como paradigma para explicar a formação de todas as demais operações mentais que envolvem o uso de signos. Assim como a linguagem, todas as funções psicológicas superiores aparecem duas vezes no curso do desenvolvimento da criança, primeiro nas atividades coletivas (inter-pessoal); logo após nas atividades individuais (intra-pessoal). Desta forma, a construção do real parte do social (interação 
com outros) e vai sendo internalizadas para se tornar individual. Como Marx e Engels, Vygotsky acredita que o homem não é apenas produto de seu meio, ele é também um sujeito ativo no movimento que cria esse meio.

A linguagem é o meio através do qual se generaliza e se transmite o conhecimento. Assim, a apropriação dos conteúdos veiculados pela linguagem se dá sempre num contexto social e historicamente determinado.

Em uma aproximação as abordagens teóricas de Bakhtin e Vygotsky, pode-se perceber a linguagem como mediadora do processo social e de aprendizagem. Assim a linguagem, em sua pragmática, pode ser considerada como uma forma de ação, na qual os agentes definem e configuram posições respectivamente. Um sujeito, ao enunciar, presume um ritual social da linguagem que pode ser implícito ou não, mas que sempre é compartilhado entre os agentes (caso contrário, há falhas ou quebras na interação).

As condições de produção e de re-significação do discurso são elementos essenciais de serem pensados em tempos de cibercultura. Ambas as condições encontram-se apoiadas no contexto social, e se vêem, muitas vezes, misturadas e imbricadas. Porém, ressaltamos que as condições de enunciação nem são elementos neutros, nem determinantes causais ao enunciado, pois, como, afirma Bakhtin (apud MAINGUENNEAU, 1997, p. 53) "a situação extra-verbal nunca é apenas a causa exterior do enunciado, (visto que) ela não age do exterior como uma força mecânica".

A dialética da linguagem, que oscila entre forma de comunicação e instrumento semiótico de significação, de um lado, e formadora da consciência, de outro, apresenta uma importância fundamental no estudo da intencionalidade no qual "[...] não é o conteúdo da linguagem que é crucial, e sim o processo de se envolver dialogicamente com outra mente." (TOMASELLO, 2003, p. 252)

Considerando a linguagem como fenômeno a mediar relações sociais, de aprendizagem, de construção de sentido e de subjetivação, encaminhamo-nos à análise do gênero discursivo emergente, proveniente da comunicação verbal através de ferramentas de chats na Internet. Analisaremos, neste caso, as circunstâncias específicas de uma disciplina no Ensino Superior, nível de Pós-Graduação, que se valeu desta funcionalidade durante suas ativida- des acadêmicas. Buscamos, com esta análise, delinear formas que a enunciações assumem na interação com o outro, alunos e professor, presumido nestas circunstâncias.

\section{Gêneros emergentes}

Antes de iniciarmos o estudo de caso vamos contextualizar o nosso espaço de pesquisa enquanto gênero digital e as características apresentadas pelo mesmo.

Primeiramente, destacamos que os gêneros digitais ou também denominados de gêneros emergentes no ciberespaço são transmutações de outros gêneros prévios que utilizam programas desenhados e projetados sobre gêneros existentes (MARCUSCHI; XAVIER, 2005). Outro ponto de destaque é distinguir o gênero do programa que o suporta. Por exemplo, o gênero de comunicação através e-mail não se confunde com o programa de e-mail. Isto porque o projetista do programa pode controlar a ferramenta que desenvolveu, porém não seus usos. Assim, a existência de uma nova ferramenta de comunicação não é condição suficiente para uma forma inovadora de comunicação; novos gêneros emergem em função das interações entre usuários e as ferramentas disponíveis na sociedade. Porém, existem elementos de regularidade presentes mesmo em gêneros emergentes no ciberespaço. São eles:

- Todo gênero reflete estruturas de autoridade e relações de poder;

- Todo gênero, por ser embasado na linguagem, mantêm uma dupla funcionalidade de comunicação e ação;

- Todo gênero apresenta formas sociais de organização típicas da vida cultural no ciberespaço;

- Todos os elementos pertencentes a um gênero são histórico, social e culturalmente situados.

O que muda, então, nos gêneros emergentes? O que é mutável é justamente a centralidade na escrita, pois mesmo com a Web 2.0 ainda os gêneros no ciberespaço perpassam muito pelo universo da linguagem escrita. Porém essa escrita assume propriedades da fala e vice-versa, sendo isto uma outra pro- 
priedade mutável dos gêneros no ciberespaço. Os gêneros síncronos, como o chat abordado neste artigo, detêm muitas das propriedades da fala enquanto que os gêneros assíncronos detêm propriedades da escrita. Porém, muitas vezes estes elementos se entrecruzam no mesmo gênero, como no caso dos chat tipo Messenger (MSN, ICQ, entre outros). Por último, outra característica presente nos gêneros emergentes é a heterogeneidade de formatos e de participação, tornando-os multimediais e eliminando, desta forma, a linearidade característica da linguagem, especialmente da linguagem falada.

No caso particular do chat, este é um gênero emergente que tem seu predecessor na fala com interações face-a-face ou interações de caráter síncrono. De forma geral, o chat pode ser definido como um gênero participativo pois requer da participação ativa dos interlocutores num processo de troca de turnos, porém se diferencia da conversação ou do gênero carta pela presença de convenções estabelecidas pelos usuários que se valem de recursos da escrita, para traduzir aspectos orais (entoação, altura da voz, aspectos emocionais, etc.) (HILGERT, 2000).

Por outro lado, a superposição de mídias como escrita som e imagem presente nos atuais chats permite que se percebam índices da transmutação da conversa do cotidiano para a Web (ARAúJO, 2003, 2004).

No caso particular deste trabalho, interessa-nos o chat educacional, que embora mantenha algumas propriedades do chamado chat aberto sem duvida detém características próprias do universo educacional que funcionam como restrições do gênero aberto.

O chat educacional é um gênero digital que possibilita a troca de informações através de mensagens escritas, em tempo real, e com propósito comunicativo notadamente educacional (ARAÚJO, 2004). Para o autor, este gênero tem sua pré-existência na aula, que por sua vez é um gênero complexo.

Neste artigo se analisará o chat educacional de um ambiente virtual de aprendizagem apresentando-se alguns recortes considerados relevantes para constatação do aporte teórico neste trabalho descrito.

\section{Análise do corpus de um chat}

Este artigo deteve-se no estudo de procedimentos retóricos da linguagem teclada no ambiente de um chat educacional. Visou compreender, por meio da análise das estratégias dos locutores, como os argumentos engendrados em suas conversas sobre os conteúdos colocados em debate. Neste caso especifico, as discussões do chat versavam sobre os estudos da visão ético-estética de M. Bakhtin. Todos os integrantes do corpus participam de um grupo social torno destes estudos e estabelecem condutas e códigos compartilhados, assim como regras para que o indivíduo seja reconhecido como membro daquele grupo, portador de uma identidade em constante processo de construção e de reconstrução.

A investigação utilizou o modelo de estratégia argumentativa como instrumento para analisar o corpus da pesquisa realizada com alunos de mestrado e doutorado da Faculdade de Educação da UFRGS, na ferramenta chat do ambiente virtual de aprendizagem Teleduc.

Os recortes analisados do chat provêm do diálogo que vai além das divisões das vozes na oralidade, que se apresenta repleto de corroborações sobre determinado tema. Podemse encontrar momentos neste recorte em que as vozes se chocam, e outros que as mesmas parecem se distanciar do contexto principal, criando novos enunciados.

No recorte a seguir (Figura 1) pode-se constatar a linguagem fundamentada na palavra, a construção do individuo ocorrendo através de sua interação social.

(17:11:51) Leb fala para todos: Para Bakhtin (1998:225) o
"Discurso não reflete uma situação, ele é uma situação. Ele é uma
enunciação que torna possível considerar a performance da voz
que o anuncia e o contexto social em que é anunciado."
(17:12:14) Dna fala para Todos: Pessoal, vou sair do forum para
buscar minha filha no colégio. Volta daquí a pouco Ave, ainda não
postei uma resposta para tua fala. na volta eu comento
(17:12:44) Mis fala para Ave: na página 294 esta escrito que
quando tomo a palavra do outro (herança cultural?) e opero com
ela em uma situação determinada, com a intensão discursiva
determinada, ela já está compenetrada da minha expressão
(17:12:57) Nai fala para Todos: A palavra do outro se transforma
em "minha palavra" a medida que dialogo com ela, e, dialogando,
ela vai ao encontro do que acredito (crenças estas que são
produto de outras idéias solidificadas em mim).., ou ela me é
conveniente, considerando o objetivo que busco alcançar com
meu discurso.

FIGURA 1 - Recorte Interação Social

Percebe-se a interação entre todos os integrantes, sendo que, Leb, Mis e Nai em torno do mesmo assunto, enquanto Dna prepara sua saída do chat em função de outro com- 
promisso, porém com a promessa de retomar a discussão, numa busca por vincular-se ao grupo, ainda que vá se ausentar. Na Figura 2, elaborado com conceitos dos autores Bakhtin e Vigotsky, pode-se perceber a importância da interação social para o desenvolvimento da linguagem, e o quão relevante é a palavra para a constituição do pensamento. Demonstrando sua concepção de que a linguagem ocorre de fora para dentro, assim sendo, do social para o individual.

\begin{tabular}{|c|c|}
\hline $\begin{array}{l}\text { Linguagem: "O desenvolvimento } \\
\text { do pensamento é determinado pela } \\
\text { linguagem, isto é, pelos instrumentos } \\
\text { lingüísticos do pensamento e } \\
\text { pela experiência sócio-cultural da } \\
\text { criança."(1991:44) }\end{array}$ & $\begin{array}{l}\text { Língua: "A língua constitui um } \\
\text { processo de evolução ininterrupto, que } \\
\text { se realiza através da interação verbal } \\
\text { social dos locutores"(1997: 127) }\end{array}$ \\
\hline $\begin{array}{l}\text { Palavra: "As palavras desempenham } \\
\text { um papel central não só no } \\
\text { desenvolvimento do pensamento, } \\
\text { mas também na evolução da histórica } \\
\text { da consciência como um todo. } \\
\text { Uma palavra é um microcosmo da } \\
\text { consciência."(1991. 132) }\end{array}$ & $\begin{array}{l}\text { Palavra: "A palavra (o discurso interior) } \\
\text { se revela como o material semiótico } \\
\text { privilegiado do psiquismo. (...) se } \\
\text { apresenta como o fundamento, a } \\
\text { base da vida interior. A exclusão da } \\
\text { palavra reduziria o psiquismo a quase } \\
\text { nada."(1997:52) }\end{array}$ \\
\hline
\end{tabular}

FIGURA 2 - Quadro Conceitos

Num segundo recorte (Figura 2), se apontará para a mediação semiótica, sendo a seguir analisada na visão dos dois autores em estudo. Pode-se perceber Ave (professor), como mediador, instigando os alunos a pensar sobre um posicionamento, do texto proposto para debate, e a interação de diversos alunos no posicionamento e embasamento nas respostas de Nai, Gam, Mis e Ait. Assim como, mais questionamentos sendo inseridos por Mac, Luj.

(17:25:30) Ave fala para Todos: Outra charada para o dia de hoje, garotada: como bakthin entende a posição do leitor/ ouvinte?

(17:26:09) Mac fala para Ait: Essa é minha grande questão: Se tudo é repetição, onde se dá a autoria???

(17:26:22) Nai fala para Todos: é um co-autor

(17:26:31) Luj fala para Gam: o que é enunciado para bakhtin?? aqui coloco algumas citaçoes: "os enuniados pertencem a um unico falante, mas onde na realidade estão confundidos dois enunciados dois modos de falar dois estilos duas linguagens... " ada enunciaado é um elo da adeia compelexa de outros enunciados." então enunciado é uma produção da analise do discurso que o sujeito faz na relação dialogica com o outro??

(17:26:49) Ave fala para Todos: Belíssima questão Camila...

(17:27:45) Ave fala para Todos: Bellssima questão Camila... (17:27:05) Avem fala para Ave: Na primeira página, 262, otradutor se pronuncia que a palavra de origem, do russo, viskázivanie, ato de enunciar, de exprimir pensamentos, sentimentos ... em palavras... e assim ele nos dá dados de tradução colocando que Bakh. não trabalha com a distinção entre ambos.

(17:27:13) Mac fala para Tel: Essa é minha grande questão: Se tudo é repetição, onde se dá a autoria???

(17:27:32) Mis fala para Ave: aha!!! essa eu acho mais fácil! O ouvinte é entendido como ativo no processo de comunicação e não meramente como sujeito ativo como nas teorias linguisticas clássicas (bem, acho q é isso)

(17:27:54) Ait fala para Gam: Claro Magale! Concordo plenamente contigo, porém me pergunto se o efeito do discurso do mente con ́́, moremo. No pergunto se o efeito do discurso do presultados da ac̃a do professor sobre o aluno, já no encontro a distân fiça do profóno distancia fico com a impressão de que o aluno pode estar sob o discurso do professor sem de fato passar por uma transformação.

FIGURA 3 - Recorte Mediação Semiótica
Segundo Vygotsky:

Para compreender a fala de outrem não basta entender as suas palavras - temos que compreender o seu pensamento. Mas nem mesmo isso é suficiente - também é preciso que conheçamos a sua motivação. Nenhuma análise psicológica de um enunciado estará completa antes de se ter atingido esse plano (VYGOTSKY, 1991, p. 130)

A mediação é, segundo Vygotsky (1988), uma característica da cognição humana, referente à internalização de atividades e comportamento sócio-históricos e culturais. A mediação inclui o uso de ferramentas e de signos dentro de um contexto social. A combinação do uso desses instrumentos, chamados de mediação ou mediadores, possibilita o desenvolvimento da cognição num processo que passa do social (inter) para o individual (intra) pela internalização. Assim, a mediação é um processo dinâmico, no qual intervêm ferramentas e signos numa ação que tem a capacidade apenas de modelar a ação, mas não de a determinar. Pois, "[...] a mais sofisticada análise dessas ferramentas não pode, por si só, nos dizer como elas são aceitas e usadas por indivíduos para conduzir a ação." (WERTSCH, 1998, p. 29) Logo, a mediação é um processo que envolve o potencial das ferramentas para modelar a ação e o uso das mesmas por parte dos indivíduos, mas "ao ser incluída no processo do comportamento, a ferramenta psicológica altera todo o fluxo e a estrutura das funções mentais" (VYGOTSKY, 1981 apud WERTSCH, 1988, p. 29).

Segundo Bakhtin (2003), o enunciado (falado ou escrito) envolve múltiplos sujeitos que podem ser falantes e ouvintes, locutores e interlocutores, ou escritores e leitores, que orientam, a cada enunciado postado no chat, o caminho que uma produção discursiva coletiva seguirá nestas circunstâncias, caracterzando um movimento dialógico. Tal movimento se apresenta como um processo social a encadear estes enunciados em correntes e organiza processos de enunciação e gêneros discursivos. A palavra, assim, é como um meio dialógico, carregada de significações que, ao mesmo tempo, forjam resposta a enunciados anteriores, e presumem respostas a enunciados futuros, formando-se um ciclo de interação dialógica entre os participantes. Para Bakhtin:

Os signos são o alimento da consciência indivi- 
dual, a matéria de seu desenvolvimento, e ela reflete sua lógica e suas leis. A lógica da consciência é a lógica da comunicação ideológica, da interação semiótica de um grupo social. (BAKHTIN, 1977, p. 35-36)

Para Othero (2002), no discurso on-line, o uso da língua é empregada através de novas expressões, neologismos semânticos, emoticons e alterações ortográficas. Para ele nas conversas on-line pode-se encontrar um ritmo solto e veloz, despreocupado e coloquial; frases curtas e expressivas; palavras abreviadas ou modificadas, que visam à rapidez; predominância de uso de letras minúsculas; uso de letras maiúsculas para dar idéia de grito ou ênfase; uso de recursos gráficos para dar ênfase (pontos de exclamação, por exemplo); não emprego dos acentos. Othero (2002) afirma que tais alterações acontecem como forma de adaptação da língua para melhor servir aos usuários no momento, calor da ação.

$\mathrm{Na}$ resposta a pergunta $O$ conceito de mediação permitiria uma aproximação entre as teorias elaboradas por Bakhtin e Vygotsky?, Irene Machado responde de forma significativa a visão dos dois autores a respeito da mediação:

A aproximação entre as formulações de Bakhtin e de Vygotsky acontece no objeto comum a ambas reflexões: a palavra em sua constituição semiótica, a palavra como signo. Ainda que os encaminhamentos sejam diferenciados, os estudos sobre a linguagem orientam-se pela interação social. Graças à dinâmica da 'significação', tanto os conceitos são elaborados pelo pensamento e transformados em linguagem (Vygotsky), quanto o diálogo avança para a construção de respostas (Bakhtin). Porque depende de interação, a linguagem é mediação por excelência. Nesse caso, a palavra não é um dispositivo físico, fisiológico ou psíquico, mas uma mediação cultural sem a qual a interação não acontece. Ainda que se reconheça a convencionalidade do significado, não se credita a ela a construção do significado. Trata-se, pois, de uma distinção qualitativa. Penso que 'mediação' é um daqueles termos que passou a conceitualizar manifestações sem que se tivesse clareza de acepção conceitual. Em vez de esclarecimento sobre as várias possibilidades de emprego, a polissemia acabou revelando a vagueza do próprio termo, fragilizando o conceito. Por isso, acho importante dizer que estou falando de mediação no sentido semiótico de interação complementar, própria a todo signo. Nesta acepção, a polissemia e a vagueza cedem lugar à precisão. A linguagem é considerada mediação uma vez que é um evento cultural das interações organizadas pela palavra cuja ação constrói discursos igualmente interativos. Existe, pois, um circuito a circunscrever o conceito. Bakhtin e Vygotsky formulam os conceitos fundamentais de sua teoria na perspectiva deste circuito graças ao qual a linguagem é focalizada em sua função primordial: a função comunicativa. Aliás, esta é, igualmente, a premissa elementar do pensamento de Roman Jakobson, que teorizou sobre as diversas funções da linguagem em estudo já consagrado. Do ponto de vista da função comunicativa, tanto o discurso interior quanto o discurso egocêntrico da criança estão longe de serem confundidos com estados psíquicos. Fora do contato, nem os discursos nem o próprio pensamento acontecem. O conceito de mediação pela linguagem, tal como foi operado nas formulações de Bakhtin e de Vygotsky, acaba esclarecendo o que se pode entender por auto-comunicação sem correr o risco de incoerência. Que dizer, a auto-comunicação jamais pode ser confundida como uma ação fechada em si mesma, o que seria um contra-senso. A autocomunicação ativa a retroalimentação do sistema e, portanto, reporta-se ao discurso dentro do discurso. Na verdade, existe uma orientação cultural que vai do texto ao texto e esta é, igualmente, uma ação dialógica ou mediada. Há muitas implicações na trajetória dessas idéias que merecem reflexões mais acuradas do que essas breves incursões. (MACHADO, 2006, p. 4-5)

Souza (2001) contribui com a discussão ao expressar que o discurso eletrônico representa um tipo de comunicação escrita. O discurso eletrônico pode assumir formas que se assemelham com o discurso falado, sendo uma modalidade que usa a linguagem, e freqüentemente escapa a um enquadramento sustentando a escrita e a oralidade.

Pode-se concluir que tanto Bakhtin quanto Vygotsky afirmam que as relações entre os sujeitos somente existem na concretude da mediação semiótica constituída nas relações sociais. E que as relações sociais, consciência (faculdades mentais superiores, na visão vygotskyana) e semiose estão intimamente interligadas, na medida em que as relações sociais geram a consciência e vice-versa, via mediações semióticas. Pode-se também dizer que as faculdades mentais superiores que culminam na formação da consciência são uma construção social constituída a partir das interações semio-discursivas.

Ainda se pode analisar, na Figura 2, a posição de Bakhtin sobre a coexistência de diversos discursos inclusos num mesmo diálogo, tornados visíveis através dos registros do chat. Ainda que abordando o mesmo assunto, observa-se a intercalação do dialógo entretido entre Nai, Gam, Mis e Ait, em torno de um assunto; e de Mac, Luj em torno de outro questionamento, o que demonstra as discussões paralelas e cadeias dialógicas sendo 
transpassadas por outras numa reconstrução constante.

Segundo Bakhtin (1997), o princípio fundador da linguagem está na interação dos interlocutores, em suas produções e interpretações que vão se elaborando e dando significado ao texto, num encontro de vozes que o autor denomina de polifonia. A polifonia das diversas vozes sociais recebidas por cada sujeito, mas que estão em constante reelaboração (reconstrução), pois como o autor descreve "o ser, refletido no signo, não apenas nele se reflete, mas também se refrata" (BAKHTIN, 1997, p. 46). Portanto, o discurso uma construção híbrida, (in)acabada por vozes em concorrência e sentidos em conflito. Descreve Marques que:

O dialogismo é o permanente diálogo entre os diversos discursos que configuram uma sociedade, uma comunidade, uma cultura. A linguagem é, portanto, essencialmente dialógica e comple$x a$, pois nela se imprimem historicamente e pelo uso as relações dialógicas dos discursos. A palavra é sempre perpassada pela palavra do outro. Isso significa que o enunciador, ao construir seu discurso, leva em conta o discurso de outrem, que está sempre presente no seu. (MARQUES, 2002, p. 3)

Chega-se a conclusão que um discurso nunca está acabado, podendo ser reelaborado constantemente sob novos pontos de vista de quem o lê e analisa. E que estes ocorrem freqüentemente entrelaçados, um discursos sobre o outro, podendo ter muitas significações conforme o enfoque que forem vistos.

\section{Considerações finais}

Este artigo procurou apresentar uma análise sobre um corpus de um chat educacional com sua ênfase na linguagem vista a luz de
Vigotsky e Bakhtin. Evidencia-se o fundamental papel da interação social para a construção do conhecimento. No caso específico, através da Comunicação Mediada pelo Computador (CMC), quem vem sendo considerada uma nova forma de comunicação, mas com características encontradas em formas de comunicação orais e escritas. O que importa, neste texto, não é tanto a ferramenta em si, mas sua utilização pelo grupo as formas pelas quais essa utilização é conduzida através da mediação do professor.

Pode-se constatar que, pelo meio digital, há a presença da interatividade, polifonia, potencialização do diálogo, através de participações ativas dos sujeitos e na apresentação de conceitos e de sua recriação individual e conjunta. A mediação do professor apresentou-se de forma instigadora e provocadora nos diálogos. Evidencia-se que a postura pedagógica docente é essencial para vencer entraves que uma perspectiva dialógica possa apresentar.

Buscou-se apresentar aqui como em uma situação de CMC, em um Ambiente Virtual de aprendizagem, consegue-se promover a interação dos alunos. Através da CMC, tonrouse possível o compartilhamento de idéias, a cooperação e colaboração na construção do conhecimento e constituição da em plena interação social, o que corrobora sua relevância como ferramenta educacional. Além disso, os resultados apresentdados vêm ao encontro do apontamento de T. Todorov, um dos principais comentadores da perspectiva de Bakhtin sobre a linguagem, a respeito da relação constitutiva entre "eu" e "outro" nessa dinâmica:

\footnotetext{
"não tomo consciência de mim mesmo senão através dos outros, é deles que eu recebo as palavras, as formas, a tonalidade que formam a primeira imagem de mim mesmo. Só me torno consciente de mim mesmo, revelando-me para o outro, através do outro e com a ajuda do outro " (TODOROV, apud BRANDÃO, 2006, p. 62).
}

\section{Referências}

ARAÚJO, J.C.R. de. Chat na Web: um estudo de gênero hipertextual. 2003. Dissertação (Mestrado em Lingüística) - Programa de Pós-Graduação em Lingüística, Universidade Federal do Ceará, 2003, Fortaleza, BR-CE.

. A Conversa na Web: o estudo da transmutação em um gênero textual. In. MARCUSCHI, L.A.; XAVIER, A.C. Hipertexto e Gêneros Digitais: novas formas de construção de sentido. Rio de Janeiro: Lucerna, 2004. P. 91-109.

BAKHTIN, M. Marxismo e Filosofia da Linguagem. São Paulo: Hucitec, 1997. 
. Estética da Criação Verbal. São Paulo: Martins Fontes, 2003.

BRANDÃO, Helena H. Magamine. Introdução à Análise do discurso. Campinas: Ed. Unicamp. 2006.

ERICJSON, T. Making Sense of Computer-Mediated Communication (CMC): Conversations as Genres, CMC Systems as Genre Ecologies. In: HAWAII INTERNATIONAL CONFERENCE ON SYSTEM SCIENCES, 33., 2000, Maui. Proceedings of... [S.I.]: IEEE, 2000. V. 3, p. 3011.

HILGERT, J.G.A Construção do Texto "Falado" por Escrito: a conversação na Internet. In: PRETI, Dino (Org.). Fala e Escrita em Questão. São Paulo: Humanitas, 2000. P. 17-55. (Projetos paralelos, v. 4)

KUSCHNIR, A.N. Quem, quando, onde e por quê?: a sala de aula sob uma perspectiva sociohistórica. Disponível em: <www.maxwell.lambda.ele.puc-rio.br/cgi-bin/PRG_0599.EXE/8495.PDF?NrOcoSis=25100\&CdLinPrg =pt>. Acesso em: jul. 2008.

MACHADO, I. Entrevista. Entrevista concedida a Silnei Soares e Pedro Russi. Rastros: revista do Núcleo de Estudos de Comunicação, Joinville, ano 7, n. 7, p. 70-75, out. 2006.

MAINGUeneAU, D. Novas Tendências em Análise do Discurso. 3.ed. Campinas, SP: Pontes, 1997.

MARCUSCHI, L.; XAVIER, A.C. (Org.). Hipertexto e Gêneros Digitais. Rio de Janeiro: Lucerna, 2005.

MARQUES, M.C.S. Vozes Bakhtinianas: breve diálogo. Primeira Versão, Porto Velho, ano 1, n. 36, p. 2-5, ago. 2002.

MORATO, E.M. Linguagem e Cognição: as reflexões de Vygotsky sobre a ação reguladora da linguagem. São Paulo: Plexus, 1996.

OLIVEIRA, M.K. Vygotsky: aprendizado e desenvolvimento: um processo sócio-histórico. São Paulo: Scipione, 1993.

OTHERO, G. de Á. A Língua Portuguesa nas Salas de Bate-papo: uma visão lingüística de nosso idioma na era digital. Porto Alegre: Berthier, 2002.

SOUZA, R.A. O Discurso Oral, o Discurso Escrito e o Discurso Eletrônico. In: MENEZES, V. Interação e Aprendizagem em Ambiente Virtual. Belo Horizonte: FALE/UFMG, 2001.

VYGOTSKY, L.S. Pensamento e Linguagem. São Paulo: Martins Fontes, 1991. . Formação Social da Mente. 6. ed. São Paulo: Martins Fontes, 1998. . A Construção do Pensamento e Linguagem. São Paulo: Martins Fontes, 2001.

WERSTCH, J. Vygotsky y la formación social de la mente. Barcelona: Paidós, 1988. (Serie Cognición y desarrollo humano) .; DEL RIO, P.; ALVAREZ, A. Estudos Socioculturais da Mente. Porto Alegre: ArtMed, 1998.

Recebido em março de 2009.

Aprovado para publicação em abril de 2009.

\section{Maria Rosangela Bez}

Doutoranda em Informática na Educação do Programa de Pós Graduação em Informática na Educação da Universidade Federal do Rio Grande do Sul- PGIE/UFRGS - Porto Alegre-RS/Brasil, Mestre em Educação no PPGEDU/UFRGS, Graduada no Curso de Licenciatura em Computação do Centro Universitário FEEVALE.

\section{Liliana Maria Passerino}

Doutora em Informática na Educação pelo Programa de Pós Graduação em Informática na Educação da Universidade Federal do Rio Grande do Sul- PGIE/UFRGS - Porto Alegre-RS/Brasil, Mestre em Ciência da Computação pelo PGCC/UFRGS, Graduada em Análise de Sistema na Argentina. Pesquisadora do Centro Interdisciplinar de Tecnologias na Educacão CINTED/UFRGS e Professora da Faculdade de Educação/UFRGS.

\section{Evandro Alves}

Doutor e Mestre em Educação pelo Programa de Pós Graduação em Informática na Educação da Universidade Federal do Rio Grande do Sul- PPGEDU/FACED/UFRGS - Porto Alegre-RS/Brasil, Licenciado em Pedagogia na Faculdade de Educação/UFRGS. 